\title{
PEMBELAJARAN IPS BERBASIS NILAI - NILAI KEARIFAN LOKAL TRADISI TEGAL DESA SEBAGAI CULTURAL INTELLIGENCE
}

\author{
Nabillah Mahdiana \\ Universitas Sebelas Maret, Surakarta \\ Email: nabillahmahdiana@student.uns.ac.id
}

\begin{abstract}
Kemajuan Ilmu Pengetahuan dan Teknologi saat ini telah menimbulkan dampak positif dan juga dampak negatif dalam kehidupan manusia. Kemajuan Ilmu Pengetahun dan Teknologi telah mempermudah keberlangsungan hidup manusia, selain itu juga merusak tatanan kehidupan manusia seperti degradasi moralitas, pengerusakan lingkungan alam dan sosial serta mengikisnya dan bahkan hilangnya kearifan lokal. Rendahnya pengetahuan dan pemahaman peserta didik mengenai kearifan lokal menimbulkan permasalahan sehingga diperlukan solusi berupa pengintegrasian nilai-nilai kearifan lokal dalam pembelajaran. Pembelajaran IPS berbasis nilai-nilai kearifan lokal sebagai salah satu sarana untuk menanamkan pengetahuan dan pemahaman kepada peserta didik untuk ikut terlibat dalam menjaga dan melestarikan nilai dan budaya lokal. Kota Gresik merupakan kota yang kaya akan tradisi, hal ini terlihat dari tiap - tiap daerah yang memiliki aneka ragam jenis tradisi seperti upacara adat. Salah satu kearifan lokal upacara adat yang dilakukan oleh masyarakat Gresik secara turun temurun adalah tradisi upacara adat Tegal Desa. Disisi lain, peserta didik harus memiliki kecerdasan di luar kecerdasan kognitif, yaitu kecerdasan majemuk yang diperlukan individu untuk memahami kondisi keragaman budaya. Kecerdasan ini di namakan Cultural Intelligence. Jadi melalui pembelajaran IPS berbasis nilai nilai kearifan lokal tradisi Tegal Desa dapat menghasilkan peserta didik yang memiliki Cultural Intelligence. Metodologi yang di gunakan dalam tulisan ini adalah kualitatif dengan analisis deskriptif dan teknik pengumpulan data berupa studi kepustakaan.
\end{abstract}

\section{Kata Kunci : Pembelajaran IPS, Nilai - Nilai Kearifan Lokal, Tradisi Tegal Desa, Cultural Intelligence}

\section{PENDAHULUAN}

Transformasi dunia karena revolusi teknologi telekomunikasi dan komputer menjadi agenda utama perubahan dunia saat ini. Dunia tidak lagi di pandang sebagai benua-benua yang terpisah atau kumpulan negara yang terpisah, melainkan dunia menjadi saraf global telekomunikasi dan komputer (Suprijono:2009). Berkembang pesatnya teknologi telekomunikasi dan komputer telah membawa manusia untuk memasuki era globalisasi. 
Pembelajaran IPS Berbasis Nilai-Nilai Kearifan Lokal Tradisi Tegal Desa Sebagai Cultural Intelligence.

(Nabillah Mahdiana)

Pada era globalisasi manusia semakin mudah untuk mengakses informasi dari berbagai belahan dunia tanpa adanya hambatan. Sejalan dengan itu (Giddens:1990) menyatakan, semakin majunya ilmu pengetahuan dan teknologi di era gloalisasi ini, dunia saat ini telah lepas kendali, sehingga perkembangan dunia saat ini telah jauh dari perkataan semula. Hal ini menunjukkan bahwa, globalisasi sebagai anak kemajuan ilmu dan teknologi memunculkan berbagai resiko dan ketidakpastian baru yang melampaui kemampuan antisipasi manusia. Kemajuan ilmu pengetahuan dan teknologi akibat globalisasi menyebabkan perubahan yang kompleks pada semua bidang kehidupan manusia. Berkembangnya ilmu pengetahuan dan teknologi telah merusak tatanan kehidupan manusia seperti degradasi moralitas, pengerusakan lingkungan alam dan sosial serta mengikisnya dan bahkan hilangnya kearifan lokal.

Hilangnya kearifan lokal akan mempengaruhi nilai-nilai yang berlaku di dalam masyarakat. Nilai-nilai kearifan lokal dalam masyarakat berperan penting dan diyakini kebenarannya sehingga menjadi acuan dalam bertingkah laku masyarakat setempat. Kearifan lokal merupakan entitas yang sangat menentukan harkat dan martabat manusia dalam komunitasnya. Hal itu berarti kearifan lokal yang di dalamnya berisi unsur kecerdasan kreativitas dan pengetahuan lokal dari para elit dan masyarakatnya adalah yang menentukan dalam pembangunan peradaban masyarakatnya. Sejalan dengan itu, Quaritch Wales merumuskan kearifan lokal atau local genius sebagai "the sum of the cultural characteristic which the vast majority of a people have in common as a result of their experiences in early life". Pokok pikiran yang terkandung dalam definisi tersebut adalah (1) karakter budaya, (2) kelompok pemilik budaya, serta (3) pengalaman hidup yang lahir dari karakter budaya (Ayatrohaedi.1986:18).

Nilai adalah kualitas yang melekat suatu objek, sesuatu mengandung nilai apabila berguna, berharga, untuk harkat dan martabatnya (Andriyanto, Muslikh, 2018 : \&). Nilai-nilai kearifan lokal akan bermakna bagi kehidupan sosial apabila dapat menjadi rujukan dan bahan acuan dalam menjaga dan menciptakan relasi sosial yang harmonis. Kearifan lokal dapat di jadikan semacam simpul perekat dan pemersatu antar generasi. Menggali dan menanamkan kembali kearifan lokal secara inheren melalui pendidikan dapat dikatakan sebagai gerakan kembali pada 
basis nilai budaya daerah dan sebagai upaya membangun identitas bangsa, sekaligus merupakan filter dalam menyeleksi pengaruh budaya lain (Sariyatun,2013:231).

Pentingnya pembelajaran IPS berbasis kearifan lokal tradisi Tegal Desa di dasarkan pada asumsi bahwa : (1) kearifan lokal menjadi warisan budaya yang dapat menumbuhkan rasa memiliki dan menghargai sejarah budaya kita sendiri. (2) Tradisi upacara Tegal desa mengandung nilai-nilai sosial dan budaya yang mencerminkan masyarakat Banjarsari dan Betiring Cerme Gresik. (3). Nilai-nilai kearifan lokal sebagai benteng dalam menghadapi transformasi budaya global dan berperan penting dalam menciptakan generasi muda yang memiliki Cultural Intelligence.

Dari latar belakang di atas maka di lakukan penelitian pembelajaran IPS berbasis nilai-nilai kearifan lokal tradisi Tegal Desa sebagai Cultural Intelligence. Secara umum penelitian ini adalah (1) mendeskripsikan pembelajaran IPS berbasis kearifan lokal tradisi Tegal Desa sebagai Cultural Intelligence; (2) mendeskripsikan nilai-nilai sosial budaya kearifan lokal tradisi Tegal Desa.

\section{METODE PENELITIAN}

Penelitian ini menggunakan metode kualitatif deskriptif dan teknik pengumpulan data dilakukan melalui kepustakaan berupa buku - buku dan jurnal yang relevan dalam penelitian. Menurut Sukmadinata (2007:60-61), metode kepustakaan merupakan metode pengumpulan data yang tertumpu pada penelaahan kritis dan mendalam terhadap bahan-bahan pustaka yang relevan.

\section{HASIL DAN PEMBAHASAN}

\section{Pembelajaran IPS Berbasis Kearifan Lokal Tradisi Tegal Desa sebagai Cultural Intelligence}

Ilmu Pengetahuan Sosial (IPS) merupakan salah satu mata pelajaran yang memegang peran penting untuk mengembangkan kebudayaan. Tujuan utama pembelajaran IPS di SMP menurut Numan Sumantri (2001:44), adalah sebagai berikut: Pertama, IPS menekankan tumbuhnya nilai kewarganegaraan, moral, 
Pembelajaran IPS Berbasis Nilai-Nilai Kearifan Lokal Tradisi Tegal Desa Sebagai Cultural Intelligence.

(Nabillah Mahdiana)

ideologi, negara dan agama. Kedua, IPS menekankan isi dan metode berpikir ilmuan. Ketiga, IPS menekankan pada reflectif inquiry.

Pembelajaran IPS diberikan untuk membentuk karakter generasi muda sebagai warga negara yang demokratis dan bertanggung jawab (Arif Musadad \& Wasino.2012). Ada tiga tingkat karakter dalam pembelajaran IPS antara lain: Pertama, secara ontologi pembelajaran IPS adalah pembelajaran mengenai proses penyadaran, pemberdayaan dan pembudayaan nilai kepada anak didik untuk menjadi individu sekaligus warga negara. Kedua, secara epistimologi pembelajaran IPS harus mengedepankan pendekatan multikultur dan multiaproach, hal ini terkait dengan realitas kebhinekaan masyarakat dan keanekaragaman potensi anak didik (Tilaar:2004). Ketiga, secara aksiologis pembelajaran IPS diarahkan untuk meningkatkan tanggung jawab peserta didik sebagai individu, masyarakat negara, dan masyarakat global, atau dalam istilah formal perundangan di Indonesia yaitu menjadi warga negara yang demokratis serta bertanggung jawab (Sudarma,2007:27).

Dari tujuan Pembelajaran IPS di atas, maka sebenarnya tujuan IPS menekankan pada penanaman nilai sosial dan budaya. Penanaman nilai sosial dan budaya dalam pembelajaran IPS akan mengantarkan peserta didik untuk memiliki kesadaran budaya. Pembelajaran IPS berbasis nilai - nilai kearifan lokal sebagai salah satu bentuk pendidikan multikultural. Penanaman nilai multikultural yang di berikan kepada peserta didik sejak dini akan membentuk peserta didik untuk memiliki Cultural Intelligence.

Cultural intelligence (Kecerdasan Budaya) merupakan kemampuan individu untuk bekerja secara efektif dalam suatu kondisi dengan kebudayaan yang berbeda (Ang et al.,2007: Ang \& Dyne, 2008). Menurut ( James M dan Wulandari MP, 2014) mengatakan bahwa kecerdasan budaya merupakan salah satu bentuk khusus dari "kecerdasan majemuk" yang diperlukan individu yang lebih fokus pada kemampuan untuk memahami kondisi keragaman budaya.

Peserta didik yang memiliki Cultural Intelligence akan memiliki kepekaan sosial, kesadaran budaya ,tenggang rasa, solidaritas, dan toleransi yang baik terhadap keberagaman budaya. Oleh sebab itu, pembelajaran IPS di SMP diharapkan dapat mengantarkan peserta didik menjadi warga negara yang 
mencintai budaya serta berperan aktif dalam melestarikan budaya sebagai warisan bangsa dan negara.

Kota Gresik merupakan kota yang kaya akan tradisi, hal ini terlihat dari tiaptiap daerah yang memiliki aneka ragam jenis tradisi seperti upacara adat, baik upacara adat yang dilaksanakan untuk kepentingan bersama maupun upacara adat yang dilaksanakan untuk kepentingan seseorang.

Upacara adat Tegal Desa menarik untuk di kaji karena dalam upacara Tegal Desa terdapat banyak nilai sosial budaya yang dapat di tanamkan melalui pembelajaran IPS. Selain itu, dalam upacara Tegal Desa terdapat akulturasi budaya antara Islam dan budaya lokal yang sudah lama berkembang dan menyatu dalam kehidupan masyarakat Dusun Betiring sebelum Islam datang di daerah tersebut. Akulturasi merupakan proses sosial yang timbul bila suatu kelompok manusia dengan kebudayaan tertentu dihadapkan dengan unsur - unsur dari suatu kebudayaan asing, yang lambat laun kebudayaan asing tersebut dapat di terima dan di olah kedalam kebudayaan sendiri tanpa menyebabkan lunturnya kepribadian kebudayaan lama atau kebudayaan asli daerah (Koentjaraningrat,1990: 248).

Upacara Tegal Desa di laksanakan oleh masyarakat Banjarsari di dusun Betiring Cerme Gresik. Upacara Tegal Desa merupakan upacara tahunan yang di laksankaan seusai panen padi, tepatnya pada tanggal 27 Selo (Dzulqadah). Upacara Tegal Desa berasal dari cerita rakyat, pada zaman dahulu kala sebuah wabah penyakit menyerang Desa Bnajarsari, termasuk Dusun Betiring. Mereka memberi nama penyakit itu dengan sebutan penyakit "ho ho ". Penyakit itu sangat aneh, dimana ketika mereka terlelap tidur, atau sedang keadaan sadar tiba - tiba mereka mengigau, arah pembicaraan mereka menjadi tidak jelas, seakan akan mereka tidak sadar. Jika orang lain yang menyentuh tubuh orang yang mengigau tadi, secara langsung ia akan tertular penyakit yang sama. Oleh karena itu, para sesepuh desa berinisiatif untuk mengadakan sebuah ritual sakral untuk membersihkan lingkungan mereka dari gangguan makhluk halus. Sesudah diadakannya berbagai prosesi ritual, diadakan juga pesta selama tujuh hari tujuh malam,selama itu pula diadakan berbagai macam hiburan seperti kesenian ludruk, 
Pembelajaran IPS Berbasis Nilai-Nilai Kearifan Lokal Tradisi Tegal Desa Sebagai Cultural Intelligence.

(Nabillah Mahdiana)

tayuban, undangan Macapat dan lain sebagainya. Acara inti dari hiburan tersebut yakni pembagian makanan kepada fakir dan miskin (Wawancara Bapak Radi).

Upacara Tegal Desa adalah upacara bersih dusun yang merupakan tradisi warisan leluhur dari waktu ke waktu. Secara etimologi, Tegal Desa berasal dari bahasa Jawa yaitu "Tegal" yang berarti lapangan terbuka, pada umumnya diperuntukkan bagi ladang yang tidak di airi, dan "Desa" artinya daerah atau desa, sehingga apabila kedua kata tersebut dirangkai mengandung pengertian tanah atau kebun (ladang) desa (Darusuprapta, 1995: 1229). Sedangkan secara terminologi Tegal Desa merupakan upacara adat yang di selenggarakan untuk memelihara bumi, dalam artian bahwa kebun atau ladang desa harus di jaga dan dilestarikan dengan sebaik mungkin.

Jadi, dari beberapa pengertian diatas dapat di simpulkan bahwa upacara Tegal Desa merupakan suatu upaya untuk memelihara keseimbangan hidup antara individu anggota masyarakat dengan lingkungan alam yaitu dengan mengadakan upacara yang bersifat religius yang mempunyai maksud untuk memohon kepada Tuhan agar apa yang di lakukan dapat berhasil dengan baik. Nilai - nilai kearifan lokal dalam Tradisi Tegal Desa antara lain :

1. Nilai pendidikan agama (Religi).

Tradisi Tegal Desa yang dilakukan oleh masyarakat desa Betiring dan Banjarsari pada saat selesai panen mengajarkan nilai agama, yakni nilai syukur kepada Allah yang di wujudkan melalui selametan sedekah bumi. Selain itu, tradisi Tegal Desa sebagai tradisi warisan nenek moyang turun temurun yang wajib di jaga sehingga tradisi Tegal Desa juga mengajarkan nilai penghormatan terhadap nenek moyang dan pewarisan nilai budaya.

2. Nilai kerukunan.

Tradisi Tegal Desa sebagai lambang silaturrahmi mempererat tali kekerabatan dan persaudaraan antar warga, dan meredam konflik yang terjadi di masyarakat.

3. Nilai kebersamaan dan kekerabatan.

Tradisi Tegal Desa mengajarkan kepekaan sosial, solidaritas sosial, nilai gotong royong, kerjasama, saling bahu membahu yang tercermin dalam simbol- 
simbol dalam upacara Tegal Desa yang menyiratkan kebersamaan yang dibangun oleh penduduk dusun Betiring dan Banjarsari Cerme Gresik.

4. Nilai Budaya.

Tradisi Tegal Desa sebagai upaya pelestarian budaya nenek moyang. Tradisi Tegal Desa mengajarkan nilai budaya karena dalam pelaksanaan tradisi Tegal desa terdapat akulturasi budaya Islam dengan budaya lokal. Konsep - konsep dalam budaya Islam yang ada pada tradisi Tegal Desa di Dusun Betiring merupakan kebudayaan pendatang yang memberikan pengaruh besar terhadap budaya lokal dalam tradisi Tegal Desa.Kebudayaan Islam yang datang ke Dusun Betiring dan mempengaruhi kebudayaan lokal, khususnya dalam pelaksanaan tradisi Tegal Desa terdiri dari :

a. Bahasa, yaitu bahasa Arab. Hal ini terlihat pada doa - doa yang di bacakan pada pelaksanaan tradisi Tegal Desa yang menggunakan bahasa Arab.

b. Organisasi Sosial, yaitu Al Khidmah. Pada pelaksanaan tradisi Tegal Desa organisasi Al Khidmah memiliki peran penting sebagai pengisi acara manaqiban.

c. Agama, yaitu agama Islam yang mengajarkan aqidah, syariah, dan akhlak.

d. Kesenian, yaitu kesenian Sholawat Nabi , pertunjukan kesenian wayang kulit, serta seni bangunan seperti masjid Betiring, Cungkup Makam Sunan Giri, serta gebyok pada Makam Kulahan yang mempunyai motif Sulur.

Pembelajaran IPS Menurut (Stahl, 2002) merupakan proses sosialisasi dan pembudayaan manusia, memanusiakan manusia. Pembelajaran IPS berbasis nilainilai kearifan lokal tradisi Tegal Desa seharusnya dapat memberikan pengetahuan, pemahaman dan kesadaran tentang keragaman budaya, sehingga menumbuhkan sikap toleransi dan saling menghargai terhadap keragaman budaya. Dengan demikian maka kesadaran, pengetahuan, motivasi dan perilaku memahami perbedaan budaya sebagai indikator kecerdasan budaya harus ditumbuhkan melalui proses pembelajaran IPS di sekolah. 


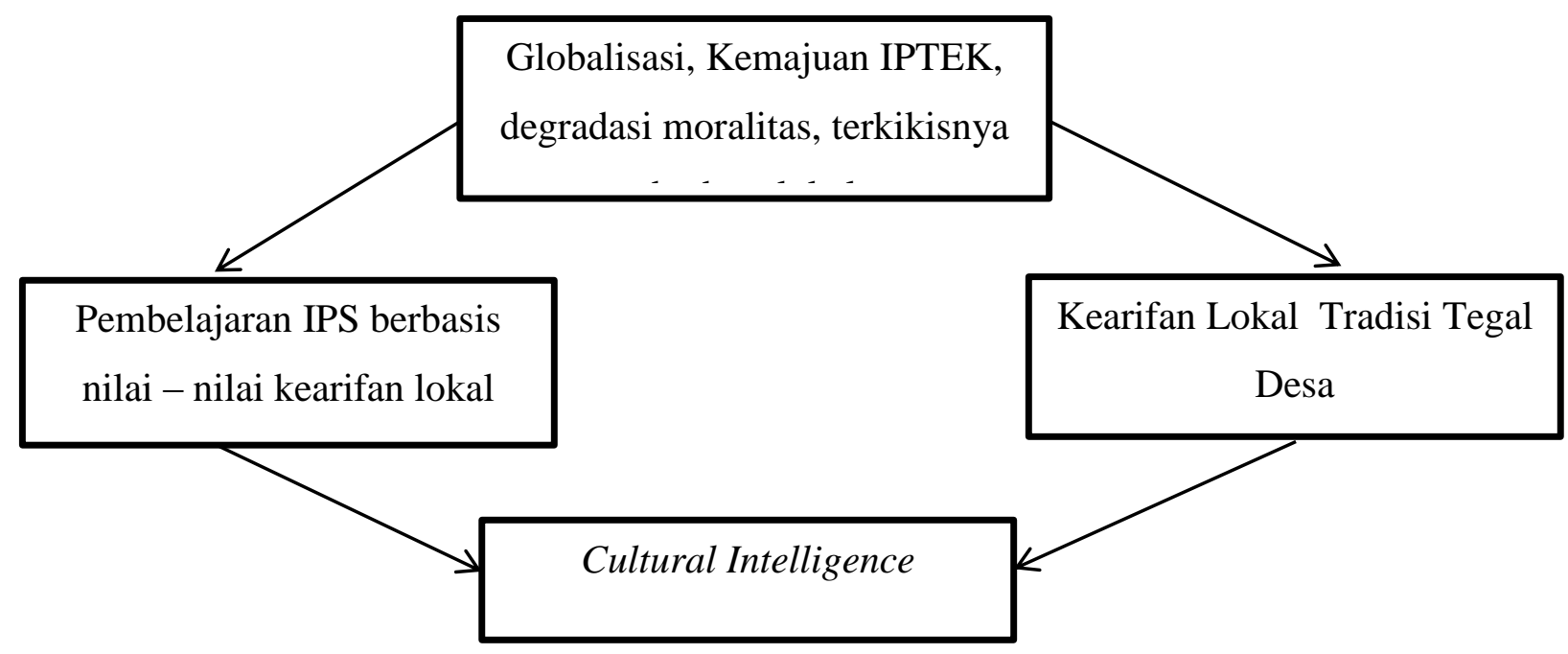

Gambar 1. Kerangka Berfikir

Berdasarkan kerangka pemikiran di atas, dapat diketahui bahwa Pembelajaran IPS yang mengembangkan potensi peserta didik secara optimal dengan mengintegrasikan nilai - nilai sosial dan kearifan lokal akan menciptakan pembelajaran IPS yang bermakna (meaningful) sehingga peserta didik memiliki Cultural Intelligence.

Kecerdasan budaya menjadi kompetensi yang penting dan harus diajarkan kepada peserta didik untuk menyikapi dan membekali peserta didik dengan keterampilan dan manajemen lintas budaya. Pembelajaran IPS sebagai wahana yang berfungsi membekali peserta didik dengan kemampuan lintas budaya dapat digunakan sebagai resolusi konflik serta sebagai jembatan untuk membangun kecerdasan budaya peserta didik sebagai generasi bangsa (Suharli,2018:154).

\section{KESIMPULAN}

Pembelajaran IPS berbasis nilai - nilai kearifan lokal tradisi Tegal Desa seharusnya dapat memberikan pengetahuan, pemahaman dan kesadaran tentang keragaman budaya, sehingga menumbuhkan sikap toleransi dan saling 
menghargai terhadap keragaman budaya. Pembelajaran IPS sebagai wahana yang berfungsi membekali peserta didik dengan kemampuan lintas budaya dapat digunakan sebagai resolusi konflik serta sebagai jembatan untuk membangun Cultural Intelligence peserta didik sebagai generasi bangsa.

\section{DAFTAR PUSTAKA}

Akhmad Arif Musadad \& Wasino. 2012. Model Pelatihan IPS - Sejarah Berbasis Pendidikan Multikultural Untuk Guru SMP. Jurnal Paramita Vol.22 No.2Juli 2012 [ISSN:0854-0039].

Andriyanto, Muslikh. 2018. Nilai-Nilai Kejuangan Sebagai Warisan Karakter Bangsa. Ombak : Yogyakarta.

Ang, S., \& Van Dyne, L., .2008. Conceptualization of cultural intelligence: Definition, distinctiveness, and nomological network. Dalam S. Ang, \& L. Van Dyne, (Eds.). Handbook on CulturalIntelligence: Theory, Measurementand Applications. Armonk, NY: M.E.Sharpe.

Ayatrohaedi, H.(ED). 1986. Kepribadian Budaya Bangsa (Local Genius). Jakarta: Pustaka Jaya.

Darusuprapta,dkk. 1995. Kamus Jawa Kuna - Indonesia. Jakarta: PT. Gramedia Pustaka Utama.

Giddens, Anthony. 1990. The Qonsequences of Modernity. Stanford: Stanford University Press.

James M dan Wulandari M., P. 2014. Cultural Intelligence Key to Future of Australia-Indonesia Relationship. Artikel online pada The Conversation Academic Rigour Journalistic Flair.

Koentjaraningrat.1990. Pengantar Ilmu Antropologi. Jakarta: Rineka Cipta.

Nana Syaodih Sukmadinata 2007. Metode Penelitian Pendidikan. Bandung: Remaja Rosdakarya.

Numan Somantri. (2001). Menggagas pembaharuan pendidikan IPS. Bandung: Remaja Rosdakarya.

Sariyatun. 2013. Pengembangan Model Pendidikan Nilai - Nilai Budaya Di SMP Berbasis Tradisi Seni Batik Klasik Surakarta. Paramita Vol.23 No.2, Juli 2013. 
Pembelajaran IPS Berbasis Nilai-Nilai Kearifan Lokal Tradisi Tegal Desa Sebagai Cultural Intelligence.

(Nabillah Mahdiana)

Sudarma, Momon. 2007. Revitalisasi IPS dalam Perspektif Global. Makalah Paralel dalam Seminar Nasional dengan tema Revitalisasi Ilmu Pengetahuan Sosial dalam Perspektif Global. Bandung: UPI, 21 November 2007.

Suharli. 2018. Mengembangkan Kecerdasan Budaya Melalui Pembelajaran IPS Di Era Global. Prosiding Profesionalisme Guru Abad XXI, Seminar Nasional IKA UNY Tahun 2018.

Suprijono, Agus. 2015. Cooperative Learning. Yogyakarta: Pustaka Belajar.

Tilaar, HAR. 2004. Multikulturalisme : Tantangan - Tantangan Global Masa Depan dalam Transformasi Pendidikan Nasional. Jakarta : Grasindo. 